\title{
Prospect of Military Educational Roles during Public Health Crises: Lessons from the COVID-19 Pandemic in South Africa
}

\author{
Adesuwa Vanessa Agbedahin, Sol Plaatje University; Komlan Agbedahin, University of the Free
} State

\begin{abstract}
This viewpoint paper examines the prospect of an effective educational role for the military during public health crises. Reflecting a broad understanding of environmental education as education to protect the public space, the authors argue that the military could provide this during times of crises. The response to the COVID-19 pandemic in South Africa included the South African National Defence Force (SANDF), thus offering a unique opportunity to inquire into this contentious possibility. At the outset of the outbreak, some scholars deemed the SANDF unfit to make any meaningful contribution to the fight against the novel coronavirus. Leadership and coordination hurdles, a longstanding legitimacy crisis and inadequate training, may justify this pessimistic view. Based on available literature and document analysis, the authors propose the viewpoint that the military can play a progressive environmental educational role during crises if (1) its educational programmes such as green soldiering are intensified, widened and adequately informed by training; (2) if more is made of the experience, cultural insights and personnel gain during peacekeeping missions; (3) if healthy civil-military relations are prioritised, along with (4) military professionalism, supported by a deeper understanding in society of the diversity of roles and skills the military could offer. The military itself needs to recognise this and not train all personnel as if they are about to enter combat with an enemy. Should these elements be present, the security forces could indeed be a force for good during times of public health crises.
\end{abstract}

Keywords: COVID-19, civil-military relations, environmental education, pandemics, SANDF

\section{Introduction and background}

This paper teases out aspects of the involvement of the military during crises (wars, pandemics, disasters) which are connected to environmental education, and highlights factors, processes and dynamics generating or influencing such initiatives. 
The outbreak of the 2019 novel coronavirus disease, also known as the COVID-19 pandemic, has triggered a proliferation of war-related metaphors from world leaders. The French president, for example, noted that "we are at war", while his German counterpart stated, "this pandemic is not a war" (Breitenbauch, 2020). In South Africa, the president opined that the post-COVID-19 recovery will require a "post-war style of state-led economic reconstruction" (Merten, 2020). These metaphorical statements reflect the intensity with which governments have experienced the pandemic, as well as mixed views about how to address it. Should the military play a critical role or not?

Breitenbauch (2020) noted indications that military strategies can play a monumental role in tackling the pandemic. Elsewhere we have argued that military strategies, like proactive social strategies by any other professionals, can contribute to the mainstreaming of Education for Sustainable Development (ESD) through their position-practice systems enhanced by capacity building and training (Agbedahin, 2016; Agbedahin \& Lotz-Sisitka, 2019). Historically, there is evidence that the military have been involved in the fight against epidemics and pandemics, providing skilled manpower and varying forms of security, medical and logistical support (Kohn et al., 2010; Arie, 2014; Gibson-Fall, 2020; Marcus, 2020). Accordingly, across the globe, soldiers have been mobilised to tackle COVID-19.

In South Africa, and at the outset of the pandemic, more than 76000 SANDF members were deployed in two batches in response to the viral threat (Madisa, 2020). Besides their traditional defence, intelligence and security functions, the deployed troops have been tasked with functions linked to environmental control, sanitation and education.

This involvement of the army is diversely appraised. But generally, in the scholarly literature, pessimistic views outnumber optimistic views. The general fear of excessive use of force, leadership and coordination problems, a legitimacy crisis, inadequate training and questionable 'military professionalism', account for this public despondency (Messelken \& Winkler, 2018; Heinecken, 2019, 2020; Bailie, 2020; Powell, 2020). It is therefore worth inquiring into the ambivalent role of the military, the relevance of the military in a disaster situation, and how environmental education and enforcement are complementary.

For the purposes of the inquiry, the authors conducted a scholarly critical analysis of the involvement of the military in the fight against COVID-19 in some countries (stated below) and particularly in South Africa. Key aspects included are green soldiering (and other environmental education activities); the benefit of peacekeeping experiences; civilmilitary relations and unequal dialogue; and military professionalism. Methodologically, this paper chiefly relies on document analysis as a qualitative inquiry method (Hodder, 2000; Atkinson \& Coffey, 2004; Rapley, 2007; Bowen, 2009).

\section{An analysis of military involvement in the fight against COVID-19}

Professionalism aims to "improve practice and enhance accountability by creating means for ensuring that practitioners will be competent and committed" (Darling-Hammond, 2009, p. 49; Agbedahin, 2016, p. 24). Globally, the military have always but varyingly been involved in responses to health crises or other forms of disasters (Kohn et al., 2010; 
Watterson \& Kamradt-Scott, 2016; Agbedahin, 2019). The insecurity that arises during such crises, the burden of diseases and large-scale deaths, predatory and rapacious behaviours from within society, and other forms of threat, can be seen to justify such a response (Hays, 2009; Agbedahin, 2012; Devermont \& Allison, 2020; Transparency International, 2020). Around the globe, several governments have mobilised the military in the response to the 2019 coronavirus crisis. One distinctive feature of this participation is its diverse nature. In Sri Lanka, for example, the response to the coronavirus crisis, at least at its initial stage, was highly militarised and also politicised (Nandakumar, 2020). In contrast to other countries where civilian agencies and health professionals oversee operations and strategies, in Sri Lanka the military has been in full control of processes including screening operations and the construction and running of quarantine centres (Nandakumar, 2020). In Germany, the military intervened to solve transport problems, while the Italian military was involved in the manufacturing of face masks and the collection of dead bodies. The military removal of corpses in Bergamo, 'Italy's Wuhan', is a case in point (Marsi, 2020; Mee, 2020). In Spain, soldiers were tasked to remove coronavirus corpses from retirement homes and care homes (BBC, 2020). These roles and contributions, potentially guiding public behaviour, demonstrating and enabling right actions, and helping to make the public space safe, can be considered as implicit and informal environmental education ${ }^{1}$ endeavours.

In South Africa, the SANDF medical teams joined in screening and testing for COVID-19 (Brandt, 2020) working with the police to ensure security, and providing rapid logistical assistance. Despite these positive efforts, military scholars and analysts have argued that the SANDF members were ill-prepared to make any meaningful contribution to combat the invisible enemy. Some warned that the involvement of the military could become a doubleedged sword' (Gibson-Fall, 2020). Some commentators have argued that a problematic shift from the apartheid military to the post-apartheid military has led to a lack of welltrained soldiers to deal with public health crises (Bailie, 2020; Heinecken, 2019). Instances of military brutality at the start of the lockdown (Bailie, 2020; Powell, 2020), as well as the existence of a civil-military gap or lack of mutual trust and respect (Heinecken, 2019), further prompted pessimistic prognoses for the South African military's participation in fighting the pandemic. Even the involvement of military healthcare personnel was not without ethical challenges (Messelken \& Winkler, 2018). Clearly, there are a number of risks characterising the involvement of SANDF members in the fight against COVID-19. However, this paper also found a number of reasons to reduce this risk, and optimise the benefit of deploying the troops. This includes the military's experience of responding to public health crises elsewhere in Africa gained during peacekeeping missions, and the existence of environmental education initiatives in the military, as discussed below.

\section{Environmental literacy, green soldiering and the fight against COVID-19}

In this section, the authors propose that green soldiering, environmental awareness and literacy, education and training can combine to prepare soldiers for educational roles during a pandemic. Viruses and other pathogens are part of the public space or environment, and 
are spread and made more harmful to humans, if special environmental management and care is not taken to mitigate against these risks. When soldiers are trained to care for the environment, they could also be equipped to share this knowledge with members of their community. When they are deployed in the fight against COVID-19, they would be better prepared and capacitated to contribute to environmental wellness, protection and the breaking of the infection chain, if they are adequately trained.

It is worth noting that the South African Department of Defence is second behind the American military to prioritise environmental management (Smit, 2018a). As far back as 1977, the foundations of environmental literacy and awareness among the military were introduced with the formulation of environmental management guidelines (ibid.). This seminal work allowed for the emergence of debates on green soldiering or a green army (Godschalk, 1999; Smit, 2018b). Green soldiering connotes being aware and conscious of environmental sustainability when carrying out military duties (Godschalk, 1999). 'Green soldiers' therefore have the skill to preserve the environment while carrying out their operations. Since they would be environmentally literate, such knowledge could be proactively and systematically shared with the public.

A study conducted by Smit (2017) on the environmental awareness of the SANDF soldiers revealed that SANDF soldiers were indeed aware of the environment and their responsibilities towards it. Environmental literacy here refers to the positive attitude of soldiers towards the environment, to demonstrating expected "environmentally beneficial behaviour"; having the necessary knowledge and acting responsibly towards the environment (Smit, 2018a). Smit (2018a) pointed out that soldiers "interact with civilian populations as well as the environment during disaster relief operations and deployments outside the country". The study found that internal policies and directives regarding environmental literacy have been developed, but that their implementation and monitoring were problematic (Smit, 2018a).

The SANDF has an ambitious Military Integrated Environmental Management Programme, comprising six sub-major programmes, viz "environmental research, environmental education and awareness training, cultural resources management, ecological management, base environmental management, and environmental planning" (Magagula, 2020, p. 170). However, Magagula (2020) argued that these programmes will only be successfully implemented if the military collaborates with relevant academic and research institutions and state organs for skills, expertise, knowledge and capacity development. Magagula (2020) also argued that environmental education and training is central to environmental management. So far, unfortunately, the environmental education and training of SANDF soldiers has been found to be insufficient and superficial (Smit \& Van der Merwe, 2018); with researchers arguing that the personnel needed more quality "environmental education and training" if they were to meaningfully contribute to the SANDF's environmental education agenda (Smit, 2018a).

We conclude that environmental education or training for SANDF soldiers is not absent, but insufficient. For soldiers involved in the fight against COVID-19, and for future pandemics and crises, an emphasis on environmental education during the pre-deployment 
period will be helpful. Soldiers who are educated can educate community members around, for instance, personal hygiene and protective gear, keeping the environment clean, effective waste management or disposal, as key strategies to break the chain of the transmission. Therefore, through constructive and friendly social interaction with community members, soldiers are postured for a significant contribution to environmental education, responsibility, and citizenship. The military involvement in fighting COVID-19 could have been better harnessed, supported and provided with focussed environmental education training and evaluation had been conducted. Partnership with educational institutions and experts in the field of environmental and sustainability education, before and during military deployment, are among the military-civil society partnerships which could have made a difference.

\section{Peacekeeping dividends and the fight against COVID-19}

Peacekeeping missions are characterised by paradoxes and contradictions (Akonor, 2017). Troop-contributing countries in peacekeeping missions are faced with financial, political, and social cost and opportunities, and varying unintended consequences that are often negative, but, we argue here, can also be positive. Peacekeeping operations are fraught with fund misappropriation, corruption and unethical appointments to higher positions for financial gains (Aoi, De Coning \& Thakur, 2007, p. 9). The culpability of peacekeepers in the 2010 cholera outbreak in Haiti (Agbedahin, 2019) and the 'ECOMOG babies' born to local women in Liberia, Sierra Leone, Guinea and Côte d'Ivoire (Aning, 2007, p. 141) are deeply problematic. But allowing unethical practices to overwhelm the scholarship of the benefits of peacekeeping, conceals minute but vital dividends or benefits. Accordingly, this viewpoint paper presents the account of an SANDF general which illustrates that the experience of individual troops could aid in domestic assignments such as the fight against COVID-19.

The account suggests that peacekeeping troops gain experience and insights when serving on missions outside their country, that could later serve as an asset for other military operations locally or internationally. In other words, we are considering the value of peacekeeping operations in capacitating the SANDF troops in the fight against COVID-19. This is based on an interview conducted by a journalist (Comins, 2020) with a former SANDF General in the United Nations peacekeeping mission in the Democratic Republic of Congo (MONUC). We try to answer the question: What have peacekeepers gained from "other people's wars" (Doss, 2020, p. 2) which could help their own country in a time of COVID-19?

The former SANDF officer was in the appropriate position to answer this question, having served in various peacekeeping missions in Africa, including Liberia, Sudan, Côte d'Ivoire (2009-2013) and the DRC in 2007 (Comins, 2020). The interview suggests that he had in the process gained much experience, and developed skills he could use during the fight against the coronavirus. As he pointed out, 
Fighting the COVID-19 pandemic is not a war but about culture and education ... COVID-19 is not about war. It is about culture and how to make people embrace different things culturally.

This officer understood the pandemic to be about culture and education. His peacekeeping mission experience in DRC with MONUC during the Ebola outbreak (UN News, 2007; World Health Organization, 2007) provided him with this insight. He had a "first-hand experience dealing with epidemics and has brought his knowledge of working with the UN's MONUC peacekeeping mission, during the 2007 Ebola outbreak in the Democratic Republic of the Congo, to his home province" (Comins, 2020).

The SANDF was deployed to DRC to help the police and create a climate conducive for people to adapt to the new 'culture' or new way of doing things, to break the transmission chain of the virus. Change can of course be resisted by communities (Yılmaz \& Kılıçoğlu, 2013). The officer noted that besides the support given to the police,

the SANDF was actively involved in rural and township areas where myths about the virus abound and education on how to use basic hygiene was most needed ... It was important to understand the culture and to use ancient practices - such as the cleaning of huts with cow dung to kill bacteria - as analogies for the modern hygienic practises of hand washing and sanitising, which are vital to beating COVID-19.

He further explained his insights as follows:

What made sense to me as an individual was that this is more about educating people to take responsibility because we need to take responsibility as individuals, which will determine whether this virus will spread or not, so let's use the defence force so they voluntarily change the culture.

He described how his peacekeeping mission during the Ebola outbreak prepared him to respond to the COVID-19 crisis:

Education, education, education. But you cannot force education, you can only persuade people of what lies before them. The only way to fight COVID-19 is to make people understand the dangers COVID-19 brings. You can arrest them every day but that won't make a difference. But you can educate one person and the entire family will wear masks and you can educate one person on hand washing. You don't have to be rich to wash your hands.

Professionally, he also acquired the skills needed to understand how to deal with myths and people's beliefs, to meaningfully participate in the socio-cultural, learning and change process, as well as to contribute. He noted:

Also, people in the townships, like KwaMashu said 'it's [the virus] a white thing, it's not for amabantawami' [my children], it's a Chinese thing, it's a US thing'. In Inanda people are living in a one-bedroom house with nine or 11 people, but in places like Glenwood people are more educated and there is space. 
The above excerpt exposes the prevailing inequalities in South Africa, and the lack of education regarding coronavirus which knows no social status, age, class and race. It also demonstrates a cultural awareness on the part of the officer. During the Ebola crisis in Liberia, it was recorded that some military healthcare workers lacked cultural awareness, and this affected their intervention (Boland, 2017). Medical anthropologists and public health experts hold that "understanding community is as important as virology" while responding to disease outbreak (Boland, 2017, p. 5). Military forces can make their health expertise available to the public in humanitarian emergencies, including in areas that cannot be reached by civilian public health programmes because of their geographical location. Military healthcare workers often have the capacity to go to remote areas (Chretien et al., 2007, p. 174); in southern Africa instances of the SANDF reaching civilians in South Africa and Mozambique during severe seasonal flooding and providing medical assistance under these high-risk disaster conditions, are examples.

We acknowledge that this singular example of the dividends of the peacekeeping mission, which emphasises the educational efforts of soldiers during epidemics and pandemics, cannot be generalised to the entire SANDF deployment in the fight against COVID-19. A more systematic study of how peacekeeping can contribute to effective domestic operations is needed. All the same, this example serves as and constitutes a pointer to the relevance and capacity that the experience gained from working outside South Africa and handling health-related crises elsewhere can bring to domestic needs. Observing other cultures often helps one understand one's own and more familiar cultures, differently. This case also demonstrates the understanding of the importance of education in the fight against pandemics and epidemics. However, educational efforts of the military would not be effective without two other critical conditions, that is, civil-military relations and military professionalism.

\section{'Social distancing' without 'social distance': The civil-military relations paradox during COVID-19}

The societal perception of soldiers as men and women carrying weapons tends to undermine their other vital functions, for example, environmental education. One reason for this is the disconnection between armies and the rest of society. While each profession has its features, it seems the military either distances itself from the rest of the society, and/or the society does not see the military as being part of the society. This mental and physical disjunction is a real legitimacy crisis of the military profession. The lack of proper education regarding the multidimensional role and significance of the military could also be partly responsible for this anomaly.

Before exploring the importance of healthy civil-military relations in the fight against COVID-19, it is worth clarifying the problematic terminology 'social distance' or 'social distancing'. Social distancing, contrary to what is promoted to break the transmission chain of COVID-19, connotes people's experience of familiarity, suggesting 'nearness and intimacy'; or unfamiliarity, suggesting farness and difference "between themselves and 
people belonging to different social, ethnic, occupational, and religious groups from their own" (Hodgetts \& Stolte, 2014, p. 1776). It is often present in everyday life (Hodgetts, et al., 2011). From a professional point of view, a healthy civil-military relation means narrowing the distance; the only way to avoid a crisis of confidence and legitimacy. So, with COVID-19, 'physical distancing' is what is needed, not 'social distancing'. The latter term is however commonly used in public messaging.

Civil-military or civilian-defence cooperation has been considered key in the fight against pandemics (Kohn, et al., 2010) and in Complex Humanitarian Emergencies which require collaboration between the military and civilians ( $\mathrm{Ma}$ et al., 2016). The Israeli partnership between the government, the military and civil society in the management of the influenza A(H1N1-09) pandemic represent a success story that should be considered by other countries. It established the possibility of a smoothly working interface between the health sector and the defence sector, to solve a medical problem.

Civil-military relation is a broad interdisciplinary area in social sciences concerned with the relationships between the military and civilian society. It deals with complex questions such as who controls the military and the relationship with civilian authorities (Feaver, 1999). Owing to the power of the military, civil-military relations are usually under threat. Feaver (1999, p. 214) explained the origin of this threat:

Just as the military must protect the polity from enemies, so must it conduct its own affairs so as not to destroy or prey on the society it is intended to protect. Because the military must face enemies, it must have coercive power, the ability to force its will on others. But coercive power often gives it the capability to enforce its will on the community that created it. A direct seizure of political power by the military is the traditional worry of civil-military relations theory and a consistent pattern in human history.

Civil-military relations refers to how the military, that is, the armed forces, relate to and interact with the rest of the society which created it for its protection, its 'primary client' in Huntington's (1957) terms. Healthy civil-military relations are needed for the good functioning of society. While there are civil-military relations between the army and its 'mother' society; there are also civil-military relations in peace operations, with societies in other countries, with their own peculiarities (Gordon, 2007). One cardinal condition for a smooth relationship between the military and civilians is military professionalism.

\section{Military professionalism and the fight against COVID-19}

The term 'unequal dialogue' was coined by Cohen (2002, p. 262) to present how the conversation between army generals and political leaders remains unequal despite the frankness and bluntness of the generals. The political leaders' authority always prevails. While civil-military relations offer political leaders the opportunity or authority to control the military, the capacity and expertise of the military should not be undermined if operations such as the fight against COVID-19 are to be successfully carried out. Educational roles may be part of unconventional roles for the military in the fight against COVID-19. 
The COVID-19 pandemic could monumentally shape institutions such as the army and discussions on post-COVID-19 military professionalism have become necessary. According to Caforio (2006, p. 3), the sociological approach is the most appropriate to study the military. Military professionalism is one cardinal aspect of 'military sociology', widely studied (Siebold, 2001; Caforio, 2006; Crabb \& Segal, 2018; Heinecken, 2019). A thorough discussion on military professionalism is not possible here, however, it is raised because of its importance in reducing the distance between society and the military (Van der Mullen, 2000) which is considered key in the fight against pandemics (Kohn et al., 2010).

While it is important to delve into the ill-preparedness of the military in the fight against the coronavirus pandemic, it is also important to begin to enquire into how the pandemic could contribute to reimagining appropriate professionalism in the military, to ensure its domestic relevance, and draw it nearer to its 'mother society' or 'first client' (Huntington, 1957).

\section{Conclusion}

This paper has examined the educational role of the military in combating the COVID-19 pandemic in South Africa. It proposes that the role of the military in response to the pandemic is diverse; beyond their traditional role of security, defence, intelligence and medical operations, the military can educationally sensitise communities about correct actions during public health crises and disasters. Contra the pessimistic view by scholars at the outset of the outbreak, the military has been contributing positively. Although there is evidence that some SANDF members have violated the Disaster Management Act regulations (Department of Defence, 2020; Powell, 2020; Skiti, 2020; South African Human Rights Commission, 2020), such violations should not completely negate the prospects of the multidimensional contributions of the military to communities and society at large.

The paper has also argued that soldiers who were previously deployed to peacekeeping missions outside South Africa, especially during disease outbreaks, could have a wealth of experience to use during public health crises like COVID-19. The understanding of the centrality of education and cultural awareness in the fight against epidemics or pandemics is crucial. For instance, experience and cultural insights that soldiers may have gained during peacekeeping and any other missions where they participated in operations against Ebola and cholera, could be an asset. The illustration provided in this paper attests to this. While not structured educational programmes, field experiences if properly reviewed and shared could have a catalytic effect on the fight against the pandemic. The paper, therefore suggests a systematic investigation into and harnessing of peacekeeping proceeds of this nature for greater domestic purposes.

Healthy civil-military relations would create an environment conducive for possible active participation of the military in education initiatives, through interactions with community members. This would allow for mutual understanding and trust between soldiers and civilians. Joint educational initiatives could be strategically and systematically embarked upon, as mentioned in the paper. There can be social distancing without civil- 
military distancing. Continuous collaboration between the various professions and experts of the army and similar experts among civilians could strengthen social ties for the common good. A reductionist understanding and interpretation of the role of the army have been prevalent; soldiers are known only for their use of force and heavy ammunition.

The domestic relevance of the military has not been obvious, except their roles at borders and other strategic areas where their socially perceived function is reduced to that of drawing fire. A collaboration for instance between military engineers, medical personnel, and their civilian counterparts, could be beneficial to society in crises where human resources and safe physical access are issues. The professional zeal and acumen demonstrated by soldiers during post-war reconstruction, for instance, could be harnessed and used. The military in peacekeeping missions interact with communities to help; a wealth of skills and experience arises from this interaction which should be profitably channelled back home following the mission.

The paper also argues that, by building on the military's existing environmental management and environmental literacy initiatives, and better deploying, intensifying and expanding green soldiering, communities can benefit from soldiers' awareness and knowledge. Owing to the recent progressive awareness of environmental issues (a shift in perspective), and its multidimensional roles in times of crisis, the military could be considered a key role player in the quest for a sustainable environment. Drawing on the lessons learned, we argue that by widening and intensifying educational programmes such as green soldiering and green militarisation, harnessing peacekeeping dividends, and encouraging healthy civil-military relations and military professionalism, armies such as SANDF have much to offer in the fight against COVID-19 and other related pandemics or crises. Military professionalism requires soldiers to consider the mother society as not the enemy but their primary client, and this should guide all educational initiatives.

The paper has highlighted some aspects of the educational roles the military could play in protecting people and limiting 'the disruption of the public space' in the context of COVID-19. The pandemic is ongoing and new dimensions of this phenomenon will need to be inquired into. The paper thus serves as a springboard for further engagement with the issues.

It is worth noting that this paper is a transdisciplinary work. We acknowledge that the connection between environmental education and military operations has not been prominently made in the literature, theory, and practice of the field. Accordingly, this paper constitutes a novel contribution that does not seek to theorise the field, but to seize the moment and the current debates to examine the prospect of the role of the military in environmental education in broader public health crises. It offers an opportunity for the emergence of related learning and research involving strategic, multi-disciplinary, multisectoral, and multi-stakeholder engagement. 


\section{Notes on Contributors and their Contributions}

\section{Lead author}

Agbedahin, Adesuwa Vanessa

Dr Adesuwa Vanessa Agbedahin is the Programme Manager for Academic Career Path Development at Sol Plaatje University. Her scholarly interests are in Education for Sustainable Development (ESD), sustainability learning and change processes in higher education, academic career development, social research, and transformation.

\section{Co-author}

Agbedahin, Komlan

Dr Komlan Agbedahin has a $\mathrm{PhD}$ in Sociology, and has taught research methods, sociology and industrial sociology courses. Based at the University of Free State, his current scholarly interests include empirical research methods, work-family balance, education and institutional change, army and society, social justice and grassroots diplomatics.

\section{Percentage contribution}

\begin{tabular}{|l|l|c|}
\hline Areas of contribution & Author & $\begin{array}{c}\text { Percentage } \\
\text { contribution }\end{array}$ \\
\hline \multirow{2}{*}{ Conception or design of the paper, theory or key argument } & A. V. Agbedahin & $50 \%$ \\
\cline { 2 - 3 } & K. Agbedahin & $50 \%$ \\
\hline \multirow{2}{*}{ Drafting the paper } & A. V. Agbedahin & $50 \%$ \\
\cline { 2 - 3 } & K. Agbedahin & $50 \%$ \\
\hline \multirow{2}{*}{ Critical review of paper } & A. V. Agbedahin & $55 \%$ \\
\cline { 2 - 3 } & K. Agbedahin & $45 \%$ \\
\hline
\end{tabular}

\section{References}

Agbedahin, A.V. (2016). A morphogenic and laminated system explanation of position-practice systems and professional development training in mainstreaming education for sustainable development in African universities. Unpublished doctoral thesis, Rhodes University, Grahamstown.

Agbedahin, A.V. \& Lotz-Sisitka, H. (2019). Mainstreaming education for sustainable development: elaborating the role of position-practice systems using seven laminations of scale. Journal of Critical Realism, 103-122.

Agbedahin, K. (2012). Young veterans, not always social misfits: A sociological discourse of Liberian transmogrification experiences. Unpublished doctoral thesis, Rhodes University, Grahamstown. 
Agbedahin, K. (2019). The Haiti cholera outbreak and peacekeeping paradoxes. Peace Review, 31(2), 190-198.

Akonor, K. (2017). UN Peacekeeping in Africa: A Critical Examination and Recommendations for Improvement. Cham: Springer.

Aning, K. (2007). Unintended consequences of peace operations for troop-contributing countries from West Africa: The case of Ghana. In C. Aoi, C. de Coning \& R. Thakur (Eds.), Unintended consequences of peacekeeping operations. Tokyo: United Nations University Press. pp. 133-155.

Aoi, C., De Coning, C. \& Thakur, R. (2007). Unintended consequences of peacekeeping operations. Tokyo: United Nations University Press.

Arie, S. (2014). Only the military can get the Ebola epidemic under control: MSF head. BMJ, 349, g6151. doi:10.1136/bmj.g6151

Atkinson, P.A. \& Coffey, A. (2004). Analysing documentary realities. In D. Silverman (Ed.), Qualitative research: Theory, method and practice (2nd ed.). London: Sage. pp. 56-75.

Bailie, C. (2020, May 28). South Africa's military is not suited for the fight against COVID-19. Here's why. Retrieved from The Conversation: https://theconversation.com/southafricas-military-is-not-suited-for-the-fight-against-covid-19-heres-why-138560

BBC News. (2020, March 24). Coronavirus: Spanish army finds care home residents 'dead and abandoned'. Retrieved from BBC News: https://www.bbc.com/news/worldeurope-52014023

Boland, S. (2017). The next Ebola: Considering the role of the military in future epidemic response. London: Royal Institute of International Affairs.

Bowen, G.A. (2009). Document analysis as a qualitative research method. Qualitative Research Journal, 9(2), 27-40.

Brandt, K. (2020, May 19). 38 SANDF medical teams assisting in the fight against COVID. Retrieved from Eyewitness News website: https://ewn.co.za/2020/05/20/38-sandfmedical-teams-assisting-in-the-fight-against-covid-19-across-sa

Breitenbauch, H. (2020, April 27). How military strategy can aid the response to COVID-19. Retrieved from World Politics Review: https://www.worldpoliticsreview.com/ articles/28714/how-military-strategy-can-aid-the-response-to-covid-19

Caforio, G. (2006). Introduction. In G. Caforio, Handbook of the Sociology of the Military. New York: Springer. pp. 3-6.

Chretien, J.-P., Blazes, D.L., Coldren, R.L., Lewis, M.D., Gaywee, J., Kana, K., ... Gaydos, J.C. (2007). The importance of militaries from developing countries in global infectious disease surveillance. Bulletin of the World Health Organization, 85(3), 174-180.

Cohen, E.A. (2002). Supreme command: Soldiers, statesmen and leadership in wartime. New York: The Free Press.

Comins, L. (2020, June 2). Education is key in war against Covid-19. Retrieved from https:// www.iol.co.za: https://www.iol.co.za/mercury/news/education-is-key-in-war-againstcovid-19-48852462 
Crabb, T. \& Segal, D.R. (2018). Comparative systems of analysis: Military sociology in the United States and Europe. In G. Caforio \& M. Nuciari (Eds.), Handbook of the sociology of the military (2nd ed.). Cham: Springer. pp. 61-86.

Darling-Hammond. (2009). Teaching and the change wars: The professionalism hypothesis. In A. Hargreaves \& M. Fullan (Eds.), Change wars. Bloomington: Solution Tree. pp. 45-68.

Department of Defence. (2020, May 31). Defence on arresting soldier for possession of illegal cigarettes during Coronavirus Covid-19 Level 4. Retrieved May 3, 2021, from South African Government: https://www.gov.za/speeches/military-police-arrestsoldier-possession-consignment-cigarettes-under-national-lockdown

Devermont, J. \& Allison, S. (2020, May 2). Covid-19 in Africa: The good news and the bad. Retrieved from Mail \& Guardian website: https://mg.co.za/article/2020-05-02-covid19-in-africa-the-good-news-and-the-bad/

Doss, A. (2020). A peacekeeper in Africa: Learning from UN interventions in other people's wars. Boulder: Lynne Rienner.

Feaver, P.D. (1999). Civil-military relations. Annual Review of Political Science, 2, 211-241.

Gibson-Fall, F. (2020, April 3). Coronavirus: How to avoid military responses becoming doubleedged swords. Retrieved from The Conversation website: https://theconversation.com/ coronavirus-how-to-avoid-military-responses-becoming-double-edged-swords-135262

Godschalk, S.K. (1999). Green soldiering in the context of integrated training management. Paper delivered at International Workshop on Integrated Range Management, Savannah, Georgia USA, 8-10 December 1999.

Gordon, S. (2007). Unintended consequences of civil-military cooperation in peace operations. In C. Aoi, C. De Coning \& R. Thakur (Eds.), Unintended consequences of peacekeeping operations. Tokyo: United Nations University Press. pp. 109-129

Hays, J.N. (2009). The burdens of disease: Epidemics and human response in Western history. New Brunswick: Rutgers University Press.

Hazan, V.M., Balicer, R. D., Groto, I., Zarka, S., Ankol, O. E., Bar-Zeev, Y., ... Ash, N. (2010). The military role in a flu pandemic. Harefuah, 149(1), 9-13, 64.

Heinecken, L. (2019). South Africa's post-apartheid military: Lost in transition and transformation. Cape Town: UCT Press.

Heinecken, L. (2020, April 2). COVID-19: South Africa's neglected military faces 'mission impossible'. Retrieved from The Conversation website: https://theconversation.com/ covid-19-south-africas-neglected-military-faces-mission-impossible-133250

Hodder, I. (2000). The interpretation of documents and material culture. In N.K. Denzin \& Y.S. Lincoln (Eds.), Handbook of qualitative research (2nd ed.). Thousand Oaks, CA: Sage. pp. 703-715.

Hodgetts, D. \& Stolte, O. (2014). Social distance. In T. Teo, Encyclopedia of Critical Psychology. London: Springer. pp. 1776-1778

Hodgetts, D., Stolte, O., Radley, A., Leggatt-Cook, C., Groot, S. \& Chamberlain, K. (2011). 'Near and far': Social distancing in domiciled characterisations of homeless people. Urban Studies, 48(8), 1739-1753. 
Kohn, S., Barnett, D.J., Leventhal, A., Reznikovich, S., Oren, M., Laor, D., ... Balicer, R.D. (2010). Pandemic influenza preparedness and response in Israel: A unique model of civilian-defence collaboration. Journal of Public Health Policy, 31, 256-269.

Ma, H., Dong, J.-P., Zhou, N. \& Pu, W. (2016). Military-civilian cooperative emergency response to infectious disease prevention and control in China. Military Medical Research, 3(39), 1-5.

Madisa, K. (2020, April 23). Why the war on Covid-19 needs an extra 73,180 soldiers. Retrieved from Times Live website: https://www.timeslive.co.za/news/southafrica/2020-04-23-why-the-war-on-covid-19-needs-an-extra-73180-soldiers/

Magagula, H.B. (2020). Military integrated environmental management programme of the South African National Defence Force. South African Geographical Journal, 102(2), 170-189.

Marcus, J. (2020, March 21). Coronavirus: Five things the military can do during pandemic. Retrieved from https://www.bbc.com/news/world-51984199

Marsi, F. (2020, March 19). Coronavirus: Army drafted in to help move corpses from 'Italy's Wuhan'. Retrieved from The Independent website: https://www.independent.co.uk/ news/world/europe/coronavirus-italy-army-deaths-corpses-bodies-bergamocases-a9411401.html

Mee, E. (2020, March 19). Coronavirus: Italian army called in as crematorium struggles to cope with deaths. Retrieved from Sky News website: https://news.sky.com/story/ coronavirus-italian-army-called-in-to-carry-away-corpses-as-citys-crematorium-isoverwhelmed-11959994

Merten, M. (2020, June 19). Covid-19 'a dark cloud with a silver lining': A post-war style of state-led economic reconstruction. Retrieved from Daily Maverick website: https://www. dailymaverick.co.za/article/2020-06-19-covid-19-a-dark-cloud-with-a-silver-lining-apost-war-style-of-state-led-economic-reconstruction/\#gsc.tab=0

Messelken, D. \& Winkler, D. (2018). Ethical challenges for military health care personnel: Dealing with epidemics. New York: Routledge.

Nandakumar, T. (2020, Spring). A military mindset: Sri Lanka's response to the coronavirus pandemic. Retrieved from the Polis Project website: https://thepolisproject.com/ militarization-of-medicine-sri-lankas-response-to-the-coronavirus-pandemic/\#. XuDIWEUzbIU

Powell, C. (2020, May 21). Rule of law has moved centre stage in lockdown: what it is and why it matters. Retrieved from The Conversation website: https://theconversation. com/rule-of-law-has-moved-centre-stage-in-lockdown-what-it-is-and-why-itmatters-139045

Rapley, T. (2007). Doing conversation, discourse and document analysis. London: Sage.

Siebold, G.L. (2001). Core issues and theory in military sociology. Journal of Political \& Military Sociology, 29(1), 140-159.

Skiti, S. (2020, October 22). SANDF hid R200m expenditure on 'Covid' drug it can't use. Retrieved May 3, 2021, from Mail \& Guardian website: https://mg.co.za/coronavirusessentials/2020-10-22-sandf-hid-r200m-expenditure-on-covid-drug-it-cant-use/ 
Smit, H.A. (2017). Military environmental literacy in South African army. Unpublished doctoral thesis, Stellenbosch University. Retrieved from http://scholar.sun.ac.za/ handle/10019.1/102784

Smit, H.A. (2018a, July 22). Do soldiers care about the environment? A study in South Africa suggests they do. Retrieved from The Conversation webssite: https://theconversation. com/do-soldiers-care-about-the-environment-a-study-in-south-africa-suggests-theydo-99965

Smit, H.A. (2018b). How green is your army? The military environmental narrative of the South African Army. South African Geographical Journal, 100(3), 308-325.

Smit, H.A. \& Van der Merwe, J. H. (2018). Military environmental literacy in the South African army. Scientia Militaria, 46(1), 59-77.

South African Human Rights Commission. (2020, April 14). Media Statement: SAHRC Calls on the State - Including the SANDF and SAPS - to Uphold and Respect Human Rights during Lockdown. Retrieved May 3, 2021, from South African Human Rights Commission website: https://www.sahrc.org.za/index.php/sahrc-media/news-2/ item/2326-media-statement-sahrc-calls-on-the-state-including-the-sandf-and-sapsto-uphold-and-respect-human-rights-during-lockdown

Transparency International (2020). Corruption and the Coronavirus. (2020, March 18). Retrieved from Transparency International website: https://www.transparency.org/ en/news/corruption-and-the-coronavirus\#

UN News. (2007, September 26). Top UN official in DR Congo visits Kananga to assess security, Ebola situation. Retrieved from UN News website: https://news.un.org/en/ story/2007/09/232982-top-un-official-dr-congo-visits-kananga-assess-security-ebolasituation

Van der Mullen, J. (2000). The Netherlands: The final professionalization of the military. In C. C. Moskos, J. A. Williams \& D. R Segal (Eds.), The postmodern military: Armed forces after the cold war. New York: Oxford University Press.

Watterson, C. \& Kamradt-Scott, A. (2016). Fighting flu: Securitization and the military role in combating influenza. Armed Forces \& Society, 42(1), 145-168.

World Health Organization. (2007, October 10). Outbreak of Ebola haemorrhagic fever in DRC. Retrieved from World Health Organization website: https://www.who.int/ features/2007/ebola_cod/en/

Yılmaz, D. \& Kılıçoğlu, G. (2013). Resistance to change and ways of reducing resistance in educational organizations. European Journal of Research on Education, 1(1), 14-21.

\section{Endnotes}

1 In Japan, one term used for environmental education translates into "education against the disruption of the public space". 